\title{
A CLINICOPATHOLOGIC REVIEW OF FIBROADENOMA IN MAKURDI, NORTH-CENTRAL NIGERIA
}

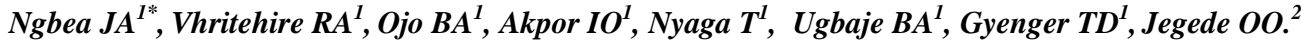 \\ Department of Anatomical Pathology, College of Health Sciences, Benue State University. ${ }^{1}$ \\ Department of Morbid Anatomy, College of Health Sciences, Bingham University, Jos. ${ }^{2}$
}

*Correspondence Author: Dr. Ngbea JA., Department of Anatomical Pathology, College of Health Sciences, Benue State University. E-mail: joenor2013@gmail.com

Received date: March $1^{\text {st }}, 2018$, Accepted date: April $9^{\text {th }}$, 2018. Published date: April $20^{\text {th }}, 2018$

\begin{abstract}
Fibroadenomas have been reported as the most common benign (non-cancerous) tumours of the female breast and are most common in women in their 20s and 30s. The clinical course and diagnosis of fibroadenoma as a benign breast lesion remains favourable except in cases of benign proliferative disease which has increased risk for breast cancer in about $0.01 \%$. This retrospective study was to determine the prevalence of fibroadenoma in female breasts. A six year review of all patients with clinicopathologic diagnosis of fibroadenoma was carried out. A total of 110 cases of fibroadenoma constituting $39.9 \%$ of benign breast disease were reported within the study period. The age range of cases was 10-70 years with a peak incidence at 20-29 years. The study showed a high prevalence of fibroadenoma in our centre. Fibroadenoma was the most common benign tumour of female breast in Makurdi, North-Central Nigeria. We therefore recommend routine mammographic screening of high risk groups and histologic assessment of all breast lumps. This will aid early detection, intervention and reduction in the associated, though small, incidence of breast cancers.
\end{abstract}

Keywords: Benign breast disease, Fibroadenoma, Makurdi.

\section{Introduction}

Fibroadenoma (FA) is the most common benign tumour of the female breast, especially in their 20 s and 30s and are frequently multiple and bilateral. ${ }^{1}$ Young women present with palpable lumps while older women present with mammographic density or mammographic calcification., ${ }^{2,3}$ Majority of these lumps which mimic or are suspected to be breast cancers clinically or radiologically are later found to be fibroadenoma histologically. The clinical course and diagnosis of fibroadenoma as a benign breast lesion remains favourable except in cases of benign proliferative disease which has increased risk for breast cancer in about $0.01 \%$ and is hormone related. ${ }^{4}$ Dietary risk factors for breast cancers such as high intake of meat and fats have been associated with greater risk of benign disease. ${ }^{5,6}$ Hormonal events also play a role but the use of antiestrogens, obesity and use of oral contraceptives are associated with a decrease risk. ${ }^{7,8}$

Fibroadenoma is a biphasic tumour that represents a hyperplastic breast lobules called aberrations of normal development and involution., ${ }^{9,10}$ it is a hormone dependent neoplasm that lactates during pregnancy and involutes along with the rest of the breast in premenopause. ${ }^{11}$ Espteisn-Barr Virus is suspected to play a causative role in the development of the neoplasm in immunosuppressed patients. ${ }^{12,13}$ Studies done within and outside Nigeria have documented the preponderance of Fibroadenoma as the commonest benign breast disease. In United States of America (USA), Fibroadenoma was discovered to be the most common breast lesion 
accounting for $67-94 \%$ of all biopsies in women under the age of 20 years. ${ }^{14}$

In African population, studies have shown increased incidence of FAs in young African-American women with decrease mean age, increase size of the tumour, and increase incidence of multifocal and bilateral tumours. ${ }^{15}$ The findings of the USA and other African series are compatible with report from Zaria, ${ }^{16}$ Gombe, ${ }^{17}$ Ife, ${ }^{18}$ Calabar, ${ }^{19}$ and Benin $^{20}$ Nigeria. Benue State University Teaching Hospital Makurdi is one of the tertiary health centres offering histopathology services in Benue State with an estimated population of 8 million people. This study examined the Clinicopathologic features of FA in Makurdi, and compared them with those in the general population and other parts of the World.

\section{Materials and methods}

This was a retrospective study of breast biopsy specimens from all benign breast diseases in Benue State University Teaching Hospital from March 2012 to February 2018 inclusive. Archival records and paraffin embedded tissue blocks were retrieved and stained; Clinical data were obtained from histology request forms. Analyses were on the basis of age, sex and histological lesions.

\section{Statistical Analysis}

The data collected were analysed using excel. Using simple statistics, frequencies and percentages were calculated and the results were presented in tables and pictorial forms.

\section{Results}

A total of 276 benign breast lesions were received at BSUTH, Makurdi, between March 2012 and February 2018. Of these 110 cases were fibroadenoma with the age range of 10-70 years. The peak age incidence was between 20-29 years. This was followed by fibrocystic changes (FCCs) with 90 cases which accounted for (32.6\%). Others were lactating changes, 20 cases (7.2\%), intraductal papilloma 8 cases $(2.9 \%)$, tubular adenoma 8 cases $(2.9 \%)$, chronic non-specific mastitis $8(2.9 \%)$, acute mastitis $7(2.5 \%)$ fat necrosis $6(2.2 \%)$, sclerosing adenosis 4(1.4\%), lactating adenoma 4(1.4\%), atypical lobular hyperplasia $3(1.1 \%)$, granular cell tumour $3(1.1 \%)$, benign pylloides $3(1.1 \%)$, gynaecomasia2(1.0\%)

Table1: Histological and patterns of benign breast lesion in BSUTH, March, 2012 - February, 2018

\begin{tabular}{lcc}
\hline Histopathology type & Frequency & Percentage \\
\hline Fibroadenoma & 110 & 39.9 \\
Fibrocystic change & 90 & 32.6 \\
Lactational change & 20 & 7.2 \\
Intraductal papilloma & 8 & 2.9 \\
Tubular adenoma & 8 & 2.9 \\
Chronic non-specific mastitis & 8 & 2.9 \\
Acute mastitis & 7 & 2.5 \\
Fat necrosis & 6 & 2.2 \\
Sclerosing adenosis & 4 & 1.4 \\
Lactating adenoma & 4 & 1.4 \\
Atypical ductal hyperplasia & 3 & 1.1 \\
Granular cell tumour & 3 & 1.1 \\
Benign phylloides & 3 & 1.1 \\
Gynaecomastia & 0.2 & 1.0 \\
\hline Total & $\mathbf{2 7 6}$ & $\mathbf{1 0 0}$ \\
\hline
\end{tabular}


Table 2: Age range of patients with fibroadenoma in BSUTH, March, 2013 - February2018

\begin{tabular}{|c|c|c|}
\hline Age range & Frequency & Percentage \\
\hline $0-9$ & - & - \\
\hline $10-19$ & 6 & 5.5 \\
\hline $20-29$ & 60 & 54.5 \\
\hline $30-39$ & 22 & 20.0 \\
\hline $40-49$ & 9 & 8.2 \\
\hline $50-59$ & 6 & 5.5 \\
\hline $60-69$ & 5 & 4.5 \\
\hline \multirow[t]{2}{*}{$>70$} & 2 & 1.8 \\
\hline & 110 & 100 \\
\hline
\end{tabular}

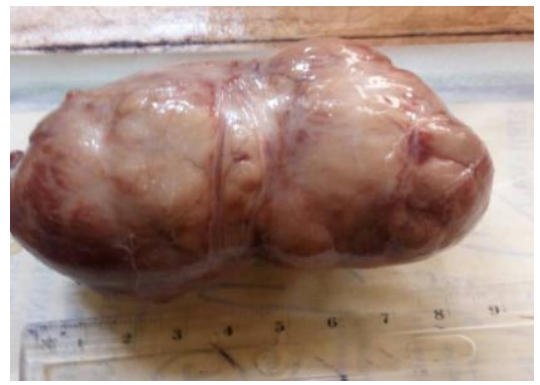

Figure1: An encapsulated firm to hard mass measuring 6 × 5x 3cm and weighing 25grams, serial sections showing grayish white solid surface.

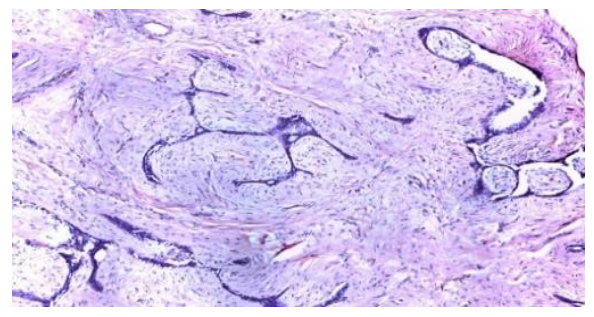

Figure 2: A fibromyxoid stroma within having proliferating ducts and ductules with most of the ducts compressed into slit-like spaces.

\section{Discussion}

As in most studies within and outside Nigeria fibroadenoma in Makurdi overwhelmingly outnumbered other benign breast lesions.(Table1) In this study Fibroadenoma was most commonly seen in patients around 20-29 years.(Table2) This is in agreement with similar studies from the USA, Ghana ${ }^{21}$ and Kenya. ${ }^{22}$ The findings are also similar to the reports from Zaria, ${ }^{16}$ Gombe ${ }^{17}$ Ife, ${ }^{18}$ and Calabar ${ }^{19}$ and Benin $^{20}$ but contrast with the findings from Ibadan $^{23}$ and Kano ${ }^{24}$ and among other Causasians where fibrocystic change was reported to be the most common benign breast disease. ${ }^{25}$ This study is consistent with an earlier study by $\mathrm{Eke}^{26}$ which shows that fibroadenoma is found most frequently in young women and together with fibrocystic change are the two main benign diseases of the breast most commonly encountered.

The fear that breast lump might be cancerous makes patients present earlier in hospitals, fortunately, majority of patients presenting to the hospitals have benign breast disease. ${ }^{27}$ Fibroadenoma of the male breast is extremely rare and no case was found in this study. In USA, fibroadenoma was discovered to be the most common benign breast disease accounting for $67-94 \%$ of all biopsies in women under the age of 
20 and is identified in $10 \%$ of all women in their lifetime. $^{14}$

A minority of fibroadenoma will disappear without treatment but most of the lesions increase in size or remain unchanged. Current management of patients with fibroadenoma in the United States varies and includes observation or surgical excisions. Ultrasound guided high intensity, Echopulse device is also used for treatment ${ }^{28}$.

Subcategories of fibroadenoma include simple fibroadenoma, giant juvenile fibroadenomas and multicentric fibroadenoma. $^{29} \quad 70-90 \%$ of fibroadenomas are simple fibroadenomas. Giant juvenile fibroadenomas are rare variant of fibroadenoma, could weigh over $500 \mathrm{~g}$ and are associated with skin ulceration and various engorgements. Multicentric FAs are the ones that occur in different quadrants of the breast accounting for $10-25 \%$ of all FAs. ${ }^{29}$ Although FAs are benign breast diseases, women with fibroadenomas are at 2.17 times increased risk of breast cancer. The incidence of malignancy arising from fibroadenoma is rare and ranges from $0.002-0.125 \% .{ }^{30}$ The exact aetiology of fibroadenoma is unknown, but studies show that estrogen influences the development of fibroadenomas. Risk factors include young age $(<35$ years old) estrogen-progestrone and contraceptive use before menopause. Fibroadenomas can also be associated with syndromes such as BeckwithWiedemann syndrome, Maffuci Syndrome and Cowden Syndrome. ${ }^{31}$

Fibroadenoma morphologically is an encapsulated, firm to hard grayish-white mass with hard white surface on serial sections.(Figure1) Histologically, fibroadenoma is a benign biphasic tumour with epithelial and stromal components in which the proliferating stroma compresses equally proliferating glands into slit-like spaces. (figure1) Just like with other tumours, the aetiology of FAs is unknown. The stromal and epithelial cells contains estrogen and progesterone receptors and the tumour often proliferates during pregnancy and regress after menopause. $^{15}$ Factors like age at menarche and menopause, parity, diet, breast feeding, smoking does not affect the incidence of FAs but oral contraceptives before age of 20 years increases the risk and immunosuppression with cyclosporine therapy increases the risk associated with Epstein Barr virus infections ${ }^{12,13}$ The stromal cells are bcl-2 positive and have been shown to be associated with neoplastic growth ${ }^{12,13}$

\section{Conclusion}

The study showed a high prevalence of fibroadenoma in our centre. Fibroadenoma was the most common benign tumour of female breast in Makurdi, NorthCentral Nigeria.

\section{Recommendation}

Future studies are recommended, to assess genetic and other risk factors as well as the morphological patterns. Intra-operative consultation is recommended in order to minimise unwarranted number of surgeries performed on patients. We also recommend routine mammographic screening of high risk groups and histologic assessment of all breast lumps. This will aid early detection, intervention and reduction in the associated, though small, incidence of breast cancers.

\section{Acknowledgement}

The authors thank the staff of Anatomic Pathology BSUTH Makurdi for providing the patients data, sectioning and processing of slides. 


\section{Reference}

1. Uwaezuoke SC, Udoye EP. Benign breast lesions in Bayelsa State, Niger Delta Nigeria: A 5 year multicentre histopathological audit. Pan Afri Med J. 2014; 19: 394.

2. Chan S, Chen JH, Chang R, Cherng Y, Chang RF, Yeh LR, Kwong J, Su MY, mammographic density and breast cancer occurred in different quadrants. BMC cancer. 2017;17:274 doi:10.1186/s12885-017-3270-0 PMCID: PMC5392962.

3. Obajimi MO, Sofoluwe AA, Adedokun BO. Sonographic breast pattern in women in Ibadan, Nigeria. Annals of Afri Med. 2014; 13(4): 145150 doi 10. 4103/1596-3519.

4. Worsham MJ, Raju U, lu M, Kakpe A, Bottrell A, Cheng J, Shah V, Savera A, Wolman Sr, Risk factors from breast disease in a diverse population. Breast Can Res treat. 2013; 118 (1): 1-7 doi 10.1007/s/0549-008-00198-8.

5. Ikwo K, Athanasius BP. Histologic patterns of Benign Breast disease in Niger Delta population. Saudi J Pathol Microbiol 2017; 2 (4): 143-46.

6. Nassar A, Visscher DW, Degnim AC, Ryan Dm, Vierkant RA, Frost $M$ et al Complex fibroadenoma and Breast cancer cohort study. Breast cancer Res treat 2015; 153 (2): 397-405.

7. Carbonaro A, Gotta L, Stracquadanio C, Formuso MR, Giunfa AD, Agati AD et al. Oral contraception and breast disease. Ameri j Nurs Sc 2012; 1 (1): 1-4. doi 10.11648.

8. Tejwanin PL, Nerkar H, Dhar A, Kataria K, ifarin S, Thulkar $\mathrm{S}$ et al . Regression of fibroadenoma with centchroman: a Randomised control trial. Indian J Surg 2015: 77 (2): 484489.

9. El-wakeu H, Umpleby HC. Systematic review of fibroadenoma as a risk factor for breast cancer 2003; 12: 302-7.

10. Kaur $\mathrm{N}$ et al. Clinicopathologic profile of benign breast conditions in Indian women: prospective study based on aberrations of normal development and involution classification. World J Surg 2012; 36 (9): 2252-58.

11. Khout $\mathrm{H}$ et al. Breast Cancer mimicking fibroadenomas in post-menopausal women. int $\mathbf{J}$ Surg 2011;9(1):2-4 doi:10.1016/j. IJSU, 2010.08.005.
12. Lau SK, Chen YY, berry GJ, Weiss LM, Epstein-Barr Virus Infection is not associated with fibroadenomas of Breast in Immunosuppressed patient after organ transplantation. Mod pathol 2004; 16 (12) : 1242-1247 doi 10. 1097/01.

13. Kleer CG, Tseng MD, Merajver SD. Detection of Epstein-Barr Virus in Rapidly Growing Fibroadenomas of the breast in Immunosuppressed Hosts. Mod pathol 2002; 15: 759-764 doi 10.1038.

14. Lokoma A, Kim ES. Minimally invasive surgical management of breast lesions. Gland Surg.2014;3(2):142-148 doi:10.3978/j.issn.2227684X.2014.04.01

15. Bewtra C. Fibroadenoma in women in Ghana. Pan Afri med J 2009; 2:11. doi:10.11604/pamj.2009.2.11.89

16. Yusuf LM, Odigie VI, Mohammed A. Breast masses in Zaria, Nigeria.Ann Afr Med2003;2:13-6

17. Mayun AA, Pindiga UH, Babayo UD. Pattern of histopathological diagnosis in breast lesions in Gombe, Nigeria. Niger j Med 2008; 17: 159-62.

18. Oluwale SF,Fadiran AO, Odesanmi WO. Diseases of the breast in Nigeria.Br J Surg 1987;74:582-5

19. Otu AA. A benign breast tumours in African population . South East. J R Coll Surg Edinb 1990; 35: 373-5.[PUBMED]

20. Okobia MN, Osime UA. A clinicopathological study of benign breast diseases in Benin City, Nigeria. Niger J Surg 1998;5:64-8.

21. Prajapath CL, Jegoda RKK,Patel UA, Patel J. Breast lump in a Teaching Hospital: A 5 year study.Nat J Med Res 2014;4(1):65-7

22. Bjerregard B,Kungu A. Benign breast lesions in Kenya, A histological study.East Afri Med J1992;69:231-35

23. Ajayi OO, Adekunle O. Non-malignant breast masses in an African population. Br j Surg 1973; 60: 465-68.

24. Ochicha D, Edino ST, Mohammed AZ, Amen SN. Benign breast lesion in Kano Nig J Surg Res 2002; 4 (1): 1-5.

25. Imam MM, Solomon R, Yusuf I. Benign tumours of the breast in Kano, Northern Nigeria: A 10 year experience and review of literature. Sahel med J 2016; 19 (3): 137-41. 
26. Eke BA, Ojo BA, Okonkwo CE, Mba IN, Ngbea JA, Vhriterhire RA. Benign breast disease in Makurdi. Asian J Med Health 2017; 4 (2): 1-6.

27. Adesun Kanmi AR, Agbakuru EA. Benign breast disease at Wesley Guild Hospital, Ilesha Nigeria. Wes AfrJ Med 2001;20:146-51

28. David B. Treatment of breast fibroadenoma with high intensity focused ultrasound (HIFU): a feasibility study. J ther ultrasound 2015; 3 (1): 078 doi 10.1186/2050-5736-3 31.078.

29. Lee M, Soltanian H. Breast fibroadenomas in adolescents:current perspectives. 2015;6:15963

30. Wu YT, Chen ST, Chen CJ et al. Breast cancer arising from fibroadenoma: Collective analysis of case reports in the literature and hints on treatment policy. World j Surg Oncol. 2014; 12 (1): 335 .

31. Poh MM, Ballard TN, Wendel JJ. Beckwithwiedeman syndrome and juvenile fibroadenoma: a case report. Ann Plast Surg. 2010; 64 (6): 803806. 